\title{
Surface water quality assessment using phytoplankton and zoobenthos: a case study at Bung Binh Thien, An Giang province, Vietnam
}

\author{
Đánh giá chất lượng nước mặt sử dung phiêu sinh thực vật và động vật đáy: Trường hợp \\ nghiên cứu tại Búng Bình Thiên, An Giang, Việt Nam
}

\author{
NGUYEN, Thanh Giao
}

Department of Environmental Management, College of Environment and Natural Resources, Can Tho University. 3/2 Street, Ninh Kieu District, Can Tho City, Viet Nam

\begin{abstract}
The study aimed to evaluate water quality at Bung Binh Thien Lake, An Giang Province, Vietnam using Shannon-Wiener species diversity index $\left(\mathrm{H}^{\prime}\right)$ and associated average score per taxon (ASPT) calculated from composition of phytoplankton and zoobenthos. The water quality index (WQI) was used as the reference for the quality of surface water. The samples of surface water quality, phytoplankton, and zoobenthos were simultaneously collected at 11 sites in the dry season. The results showed that WQI (57-88) classified water quality from good to medium, $\mathrm{H}^{\prime}$ calculated using phytoplankton species (1.12-2.71) presented water quality from medium to bad whereas, (H'z) calculated (0 to 2.07) and ASPT (2-4.21) calculated from zoobenthos species divided water quality from bad to very bad. The findings revealed that assessing water quality should not totally only relied on diversity indices ( $\mathrm{H}^{\prime}, \mathrm{ASPT}$ ) but also carefully consider compositions of phytoplankton and zooplankton. In addition, interpretation of the biodiversity indices for water quality examination should involve the experts in the relevant fields.
\end{abstract}

Nghiên cứu nhằm đánh giá chất lượng nước tại hồ Bung Binh Thiên, tỉnh An Giang, Việt Nam sử dụng chỉ số đa dạng loài Shannon-Wiener ( $H^{\prime}$ ) và chỉ số tính điểm trung bình bình theo họ (ASPT) được tính từ thành phần của phiêu sinh thực vật và động vật đáy. Chi số chất lượng nước (WQI) được sử dụng tham chiếu cho chất lượng nước mặt. Các mẫu chất lượng nước mặt, phiêu sinh thực vật thực vật và động vật đáy được thu đồng thời tại 11 địa điểm trong mùa khô. Kết quả cho thấy WQI (57-88) phân loại chất lượng nước từ tốt đến trung bình, H'p được tính dựa vào các loài phiêu sinh thực vật $(1,12-2,71)$ thể hiện chất lượng nước từ trung bình đến xấu trong khi, $H^{\prime} z(0-2,07)$ và ASPT (2-4,21) được tính toán từ các loài động vật đáy phân loại chất lượng nước từ xấu đến rất xấu Kết quả nghiên cứu cho thấy đánh giá chất lượng nước không chỉ hoàn toàn dựa vào các chi số đa dạng (H', ASPT) mà còn xem xét cẩn thận thành phần loài của phiêu sinh thực vật và động vật đáy. Ngoài ra, việc giải thích các chi số đa dạng sinh học nhằm tra chất lượng nước cần có sự tham gia của các chuyên gia trong các lĩnh vực liên quan.

Keywords: water monitoring, phytoplankton, zoobenthos, biodiversity index, An Giang

\section{Introduction}

Water is essential for life. Monitoring changes in water quality due to impacts of socio-economic activities such as domestic, agriculture, industry and services are important tasks. The results of water monitoring can be used effectively to manage and improve water quality. Thus, water monitoring is legalized in environmental laws and policies in most countries. There are several types of water quality monitoring such as continuous monitoring, background monitoring, flux monitoring, or impact monitoring. Choosing the right monitoring indicators would make the environmental monitoring more accurate and better serve for environmental management. For monitoring surface water quality, physicochemical parameters of the water and biological organisms associated with water environment such as phytoplankton, zooplankton and zoobenthos can also be used (Richard et al., 1997; Plafkin et al., 1989; Cao et al., 2007; Lan, 2000; Dung et al., 2011; Lien and Ut, 2016; Wijeyaratne and Kalaotuwave, 2017, Ly and Giao, 2018; Giao, 2019). Physicochemical variables include temperature $\left({ }^{\circ} \mathrm{C}\right)$, $\mathrm{pH}$, total suspended solids (TSS), turbidity, or dissolved oxygen (DO), biological oxygen demand (BOD), chemical oxygen demand $(\mathrm{CODL})$, ammonia $\left(\mathrm{NH}_{4}{ }^{+}-\mathrm{N}\right)$, orthophosphate $\left(\mathrm{PO}_{4}{ }^{3-}-\mathrm{P}\right)$, chloride $(\mathrm{Cl})$, sulfate $\left(\mathrm{SO}_{4}{ }^{2-}\right)$, heavy metals ( $\mathrm{Fe}, \mathrm{Al}$, $\mathrm{Mn}, \mathrm{Cr}, \mathrm{Cd}$ ), pesticides, antibiotics, or biological factors such as E. coli, coliform (Cho et al., 2009; Chounlamany et al., 2017; Zeinalzadeh and Rezaei, 2017). The selection of a 
set of physicochemical indicators for water monitoring depends on the characteristics of the pollution sources (Cao et al., 2007).

In addition to physicochemical parameters, phytoplankton is also selected as indicator for quality of water since its diversity and abundance that are closely related to characteristics of water environmental such as light, temperature, nutrients, carbon dioxide, bicarbonate, presence of phytoplankton consumers (i.e. zooplankton, fish) (Cao et al., 2007; Oanh and Lien, 2015; Hoang et al., 2018; Duong et al., 2019). Some phytoplankton phyla such as Bacillariophyta, Cyanophyta, Chlorophyta can be used to indicate nutrient-rich and high organic water environment (Bac, 1998; Lan, 2000; Oanh et al., 2014; Hoang et al., 2018). Cyanophyta is an indicator for static water and organic-rich water environment. Dinophyta or Pyrrophyta are used to indicate brackish and saltwater environments (Oanh et al., 2014). Similarly, zoobenthos can also be used as water quality indication since zoobenthos has a relatively longlife cycle interacting with the bottom of the water body, so it can be used to indicate water environment conditions and sediment properties (Wilhm and Dorris, 1968; Richard et al., 1997; Dung et al., 2011; Lien and Ut, 2014; Wijeyaratne and Kalaotuwave 2017; Giao, 2019). Some examples of zoobenthos classes including Oligochaeta, Polychaeta, Insecta, Gastropoda, Bivalvia and Malacostraca. Changes in environmental conditions can lead to changes in composition of zoobenthos. History of water pollution could be traced using zoobenthos. Several studies have been implemented on water indication of zoobenthos. Water quality affected by domestic wastewater, urban wastewater, aquaculture wastewater, and landfill operation has been investigated using zoobenthos (Dung et al., 2011; Oanh et al., 2014; Hoang et al., 2018; Giao, 2019).

In Vietnam, the central and local environmental management authorities have been monitoring the surface water quality mainly using physicochemical variables. However, observation of environmental quality of water using phytoplankton and zoobenthos have been recently recommended since it would help quickly diagnose environmental quality with simple, inexpensive and less pollutants generated. Certain environmental management authorities in the Vietnamese Mekong delta have been using phytoplankton and zoobenthos for water monitoring. However, limited studies have been conducted using simultaneous physicochemical, phytoplankton and zoobenthos to evaluate how each method work for water quality monitoring. This study was carried out at Bung Binh Thien, An Giang, Vietnam to assess the water quality using physicochemical phytoplankton and zoobenthos. The findings of the current study could provide important information for the selection of environmental indicators for water monitoring.

\section{Materials and methods}

\subsection{Site description}

Binh Thien Bung is the largest freshwater lake in the south of Vietnam belonging to three communes comprising Nhon Hoi, Quoc Thai and Khanh Binh, An Phu district, An Giang province. The water surface areas of lake in the dry and wet seasons are 200 and 800 ha, respectively. The average depth of lake is $4 \mathrm{~m}$, the length is approximate 2,900 $\mathrm{m}$ and the average width is $430 \mathrm{~m}$ (Department of Natural Resources and Environment, An Giang, 2014). Bung Binh Thien plays key role in socio-economic development, for examples, providing freshwater for domestic uses, cultivation and animal husbandry, and aquaculture. However, Bung Binh Thien is now severely affected by wastes from local activities (domestic, agriculture, and aquaculture) as well as from the upstream of Cambodia, for instances, fast food foam boxes, plastic bottles and pollutant-attaching sediments. In the future, Bung Binh Thien lake is planned to be a conservation area to conserve biodiversity and to reserve freshwater for daily life and other activities people in the region. For this reason, Bung Binh Thien Lake is a good selection for the current research.

\subsection{Water sampling and analysis}

Water quality characterization including physical, chemical and biological parameters was analyzed. Temperature $\left({ }^{\circ} \mathrm{C}\right)$, $\mathrm{pH}$, total suspended solids (TSS, mg/L), turbidity (NTU) are physical variables. The chemical variables are dissolved oxygen (DO, mg/L), biological oxygen demand (BOD, mg/L), chemical oxygen demand (COD, $\mathrm{mg} / \mathrm{L})$, ammonia $\left(\mathrm{NH}_{4}{ }^{+}-\mathrm{N}\right.$, $\mathrm{mg} / \mathrm{L})$, orthophosphate $\left(\mathrm{PO}_{4}{ }^{3-}-\mathrm{P}, \mathrm{mg} / \mathrm{L}\right)$ and coliform (MPN/100mL). The 10 water samples (namely S1-S10) were collected inside the lake and one sample (namely S11) was collected in the river directly connected to the lake. Locations of sample collection in Bung Binh Thien Lake was shown in Figure 1. The water samples inside the lake was collected at the onset (S10) and at the middle (S4-S9) and at the end of the lake (S1-S3). The water samples were also collected at the positions close to the lake banks (S3, S6, S9, S1, S4, and S7) and at the middle of the lake (S2, S5, and S8). The samples were collected in the dry season on 12 January 2019. Temperature and DO were measured at the field using handheld meters. The other parameters of water quality analysis and quality control were performed using standard methods (APHA, 1998).

The surface water quality was assessed by WQI following Equation (1) (National Environmental Protection Agency, 2011):

$$
W Q I=\frac{W Q I_{p H}}{100}\left[\frac{1}{5} \sum_{a=1}^{5} W Q I_{a} \cdot W Q I_{b} \cdot W Q I_{C}\right]^{1 / 3}
$$

where WQla is the WQI value of five parameters (i.e., DO, $\mathrm{BOD}_{5}, \mathrm{COD}, \mathrm{N}-\mathrm{NH}_{4}{ }^{+}$, and $\mathrm{P}-\mathrm{PO}_{4}{ }^{3-}$ ); WQIb is the WQI value of 
TSS; WQIc is the WQI value of Coliforms; WQI $I_{p H}$ is the WQI value of $\mathrm{pH}$ parameters (ranging from 6 to 8.5 ).

The WQI is ranging from 0 to 100 dividing water quality into five levels. Level 1 (100> WQI>91) is good water quality that could be used for purposes of water supply. Level 2 $(90>$ WQ $1>76)$ is also used for water supply for domestic uses but suitable treatment measures are required. Level 3 is for irrigation and other similar purposes (75>WQI>51). Level $4(50>\mathrm{WQI}>26)$ is the water suitable for transport and equivalent purposes while Level $5(25>\mathrm{WQ} />0)$ is considered to be heavily polluted water that proper treatment measures are urgently needed.

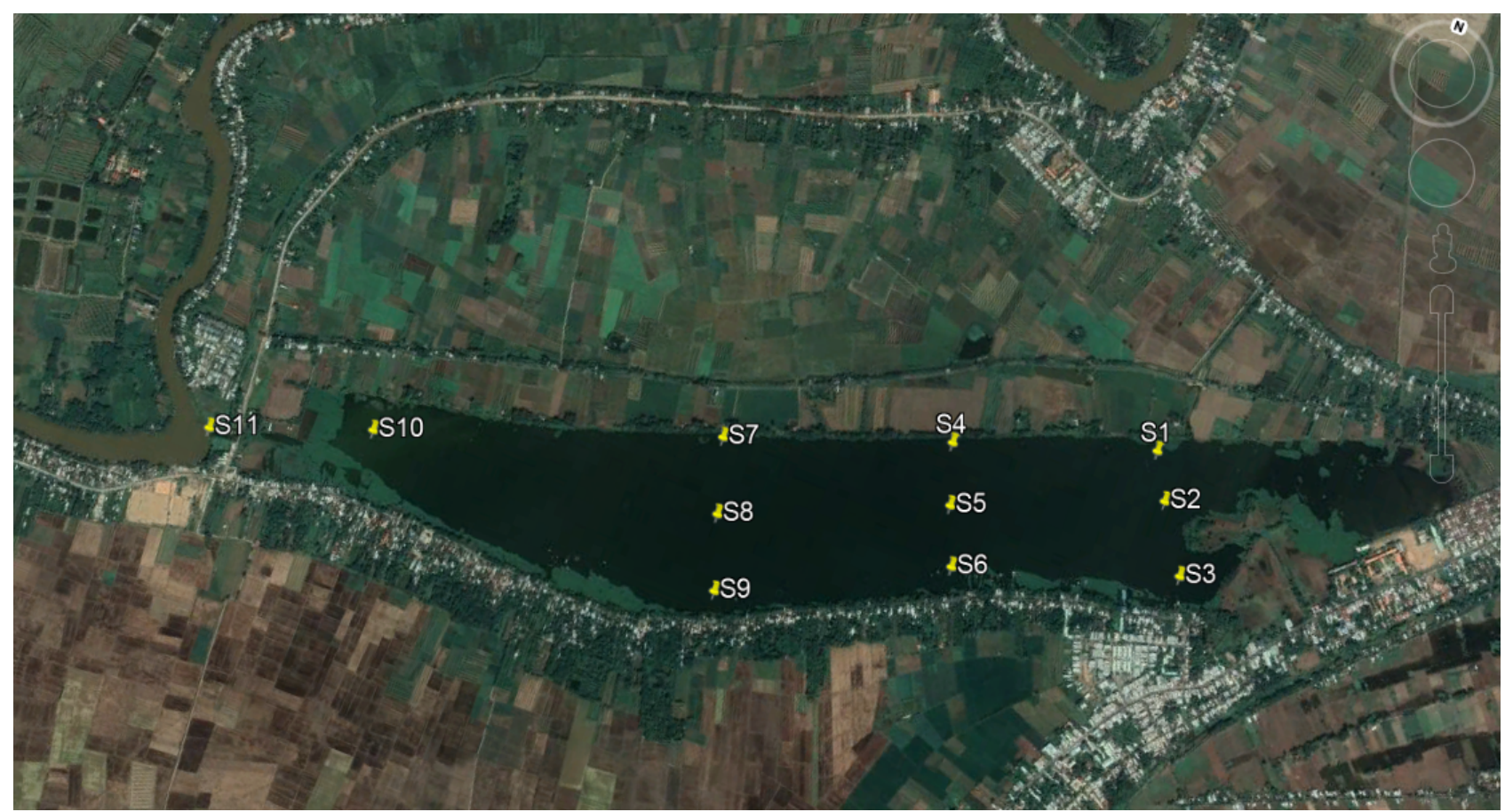

Figure 1. Locations of sample collection (Google Earth, 2019)

\subsection{Phytoplankton sampling and analysis}

The samples of phytoplankton were collected by filtering $200 \mathrm{~L}$ of water through $25-\mu \mathrm{m}$ mesh size net. The concentrated samples were placed in a $110 \mathrm{~mL}$ vials and fixed with formaldehyde 2-4\%. Qualitative analysis was performed using a microscope in 10X-40X objective and images of phytoplankton were taken to determine morphological and structural characteristics and classification according to Tien and Hanh (1997); Ho (1969); Tuyen (2003); Fernando (2002), Reynold (2006). Quantitative analysis samples were performed by counting individual phytoplankton according to the methods of Boyd and Tucker (1992). The density of phytoplankton was calculated by equation (2):

$$
Y=(X \times V c \times 1000) /(N \times A \times V t)
$$

where $\mathrm{Y}$ is phytoplankton density (individuals/liter); $\mathrm{X}$ is the number of individuals phytoplankton in the counted cells; Vc is the concentrated sample volume $(\mathrm{mL})$; $N$ is the number of counted cells; $A$ is volume of counted cells ( $1 \mathrm{~mm} 2$ ) and $\mathrm{Vt}$ is water volume collected $(\mathrm{mL})$.

The diversity of phytoplankton was examined by calculating Shannon-Wiener diversity index $\left(\mathrm{H}^{\prime}\right)$ following Equation (3) (Wilhm and Dorris, 1968):

$$
H^{\prime}=-\sum p_{i} \cdot \ln \left(p_{i}\right)
$$

where $\mathrm{pi}=\mathrm{ni} / \mathrm{N}$; ni is the numbers of ith individual; $\mathrm{N}$ is total amount of individuals in the samples. Water quality is divided at three levels of pollution based on $\mathrm{H}^{\prime}$ values. $\mathrm{H}^{\prime}$ is greater than 3 indicates good water quality or water is not polluted. $\mathrm{H}^{\prime}$ is in the range from 1 to 3 showed moderate water pollution. Finally, $\mathrm{H}^{\prime}<1$ revealed that water is highly polluted (Wilhm and Dorris, 1968).

\subsection{Zoobenthos sampling and analysis}

Zoobenthos samples were collected by Petersen grab (Wijeyaratne and Kalaotuwave, 2017. At each sampling point, collecting benthic species samples were repeated five times to increase the representative. The collected samples were sieved to $0.5 \mathrm{~mm}$ size to remove mud and debris. After that, the sieved samples were stored in nylon bags and fixed with $8 \%$ formaldehyde. The collected samples were transported to the laboratory, at which the samples were further process by eliminating all organic matters and just retained zoobenthos. The collected zoobenthos were fixed with $4 \%$ formaldehyde solution until qualitative and quantitative analyses were performed. For qualitative analysis, zoobenthos were observed by using microscope and magnifying glass to determine the structural morphologi- 
cal characteristics and classification characteristics following the taxonomy textbooks of Quynh et al., 2001; Thanh et al., 1980; Hung, 2010; Hayward and Ryland, 1990; Zamora and Co, 1986; Carpenter and Niem, 1998. For quantitative analysis, the zoobenthos in each sample were counted separately for each individual and determined density by Equation (4):

$$
D=X / S
$$

where $D$ is the density calculated by individual per $m^{2}, X$ is the number of counted individuals in the collected sample; $\mathrm{S}$ is the sampling area $(\mathrm{S}=\mathrm{n} \times \mathrm{d})$, $\mathrm{n}$ is the number of collected Petersen grab, $d$ is the open mouth area of the grab $\left(0.02 m^{2}\right)$.

Data on species composition and density of zoobenthos were used to calculate Shannon-Weiner diversity index $\left(\mathrm{H}^{\prime}\right)$ using Equation 3 (Wilhm and Dorris, 1968).

The associated average score per taxon (ASPT) was calculated based on the scored table of BMWPVIETNAM (Biological Monitoring Working Party-VIETNAM) (Quynh et al., 2000) using Equation (5) (Richard et al., 1997):

$$
A S P T=\frac{\sum_{\mathrm{i}=1}^{\mathrm{n} B M W P}}{\mathrm{~N}}
$$

where $\mathrm{N}$ is total families used for calculating tolerance scale; BMWP is BMWPVIETNAM.

\section{Results and discussion}

\subsection{Physical and chemical characteristics of water at Bung Binh Thien}

Table 1 presented the 10 physicochemical water quality variables at 11 sampling points at Bung Binh Thien in the dry season (January 2019). The temperature in the lake was in the range of $28.07 \pm 0.06-30.33 \pm 1.36{ }^{\circ} \mathrm{C}$. Former study reported that temperature in waters in Hau and field canals in An Giang province also fluctuated in the range of $29-30^{\circ} \mathrm{C}$ (averaged $29.7 \pm 0.7^{\circ} \mathrm{C}$ ) (Ly and Giao, 2018) which is in accordance with the current study. The temperatures at all sampling points are in suitable range for aquatic organisms. The $\mathrm{pH}$ in water was recorded ranged from $7.55 \pm 0.03$ to $7.85 \pm 0.01$ which is slightly basic. The $\mathrm{pH}$ measured in the lake is higher than $\mathrm{pH}$ recorded in $\mathrm{An}$ Giang's rivers (6.9 to 7.1) during 2009-2016 (Ly and Giao, 2018), but still in the favorable ranges for aquatic life since the national standard recommends $\mathrm{pH}$ should be in the range of 6.0-8.5. $\mathrm{pH}$ and temperature do not highly fluctuate and this is the common condition in tropical region (Singh et al., 2005; Chounlamany et al., 2017). Turbidity was

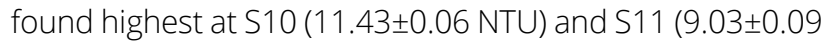
NTU) since these two points were in close relation with the river. Prior study also found that turbidity was high ranging from $12.6 \pm 7.2$ to $131.8 \pm 62.3$ NTU in the river (Zeinalzadeh and Rezaei, 2017). It was found that DO ranged from
$5.33 \pm 0.06$ to $9.17 \pm 0.38 \mathrm{mg} / \mathrm{L}$. The significant higher DO values $(p<0.05)$ were observed at the points inside the lake while the DO values sites close (S10) to the river and in the river (S11) were significantly lower $(p<0.05)$. The higher values of DO in the lake could be because diverse and abundant presence of phytoplankton and water hyacinth that release and diffuse oxygen into the water environment. It was found that DO values in the present study were higher compared to several water bodies (4.0 to $5.2 \mathrm{mg} / \mathrm{L}$ ) belonging to An Giang province over the period of 2009-2016 (Ly and Giao, 2018). The higher DO concentration could indicate better self-purification capacity of the lake. Biological oxygen demand was in the range of $9.33 \pm 0.58-11.67 \pm 0.58$ $\mathrm{mg} / \mathrm{L}$, whereas chemical oxygen demand was in the range of 14.33 $\pm 0.58-17.67 \pm 0.58 \mathrm{mg} / \mathrm{L}$. Both BOD and COD were used as indicators of organic waste concentration in water (Galal-Gorchev et al., 1993; Kazi et al., 2009). BOD and COD were found higher at the end of the lake where there are presence of active human activities such as restaurant and cafeteria. BOD averagely accounts for $65.2 \pm 1.1 \%$ of the COD indicating almost $35 \%$ of organic matters presence in the lake are recalcitrant substances. The values of organic matters in the lake exceeded the national standard 2.6 and 1.6 times for BOD and COD, respectively which could potentially pose high threat to ecological and human health. Fortunately, dissolved oxygen is high generating good environmental condition for decomposition of organic matters. BOD in BBT lake (9.33 $\pm 0.58-11.67 \pm 0.58 \mathrm{mg} / \mathrm{L})$ was significantly higher than that in Hau river and field canals (4.1$5.5 \mathrm{mg} / \mathrm{L}$ ) (Ly and Giao, 2018) indicating the water environment in the lake is more organically polluted that the other water bodies in areas of An Giang province.

Ammonium concentration were not detected (detection limit of $0.03 \mathrm{mg} / \mathrm{L})$ at S1, S3, S4, S5, S7, S8, and S9 while it was detected at S2 $(0.2 \mathrm{mg} / \mathrm{L}), \mathrm{S} 6(0.04 \mathrm{mg} / \mathrm{L}), \mathrm{S} 10(0.10$ $\mathrm{mg} / \mathrm{L})$ and S11 (0.22 mg/L). Orthophosphate was also not detected (detection limit of $0.03 \mathrm{mg} / \mathrm{L}$ ) at all sampling sites except at S11 (0.05 mg/L). During 2009-2016, orthophosphate concentration was detected in river system in An Giang province ranged from 0.02 to $0.47 \mathrm{mg} / \mathrm{L}$ (Giao and Ly, 2018) which was higher than that was detected in the BBT Lake in the dry season. Coliform density in the study site ranged from 1900 \pm 346.41 to $9300 \pm 0.00 \mathrm{MPN} / 100 \mathrm{~mL}$. The coliform at S4, S8, S10, and S11 exceeded the national standard surface water quality (allowable limit of 2500 MPN/100 mL) from 1.72 to 3.72 times. Former study found that coliform density in river networks in An Giang exceeded the national regulation by 2.14-7.04 times (Ly and Giao, 2018). The coliform data revealed that the river water was more serious contamination with fecal microorganisms than the lake water. The sources of coliform contamination are from human and animal wastes, especially the fecal materials (Bolstad and Swank, 1997; UNICEF, 2008; Ministry of Natural Resources and Environment, 2012). The overall result indicated that total suspended solids, organic matters, and coliforms could impair water quality at Bung Binh Thien. 
Table 1. Characteristics of surface water at Bung Binh Thien

\begin{tabular}{|c|c|c|c|c|c|c|}
\hline Parameter & S1 & S2 & S3 & S4 & S5 & S6 \\
\hline Temp & $29.2 \pm 0.0$ & $29.0 \pm 0.0$ & $30.3 \pm 0.1$ & $29.5 \pm 0.0$ & $29.23 \pm 0.3$ & $30.1 \pm 0.3$ \\
\hline $\mathrm{pH}$ & $7.64 \pm 0.01$ & $7.79 \pm 0.01$ & $7.85 \pm 0.01$ & $7.81 \pm 0.04$ & $7.56 \pm 0.03$ & $7.55 \pm 0.03$ \\
\hline Turbidity & $4.67 \pm 0.06$ & $3.53 \pm 0.06$ & $3.28 \pm 0.04$ & $4.33 \pm 0.08$ & $6.25 \pm 0.06$ & $3.27 \pm 0.09$ \\
\hline TSS & $46.3 \pm 0.6$ & $46.7 \pm 0.6$ & $44.0 \pm 1.0$ & $50.3 \pm 0.5$ & $48.0 \pm 1.0$ & $47.7 \pm 0.6$ \\
\hline DO & $8.8 \pm 0.2$ & $8.9 \pm 0.2$ & $7.7 \pm 0.2$ & $9.0 \pm 0.3$ & $8.1 \pm 0.1$ & $9.2 \pm 0.4$ \\
\hline COD & $17.3 \pm 0.6$ & $17.7 \pm 0.6$ & $17.0 \pm 0.0$ & $17.7 \pm 0.6$ & $15.3 \pm 0.6$ & $15.0 \pm 0.0$ \\
\hline $\mathrm{BOD}_{5}$ & $11.3 \pm 0.6$ & $11.7 \pm 0.6$ & $11.0 \pm 0.0$ & $11.7 \pm 0.6$ & $10.0 \pm 0.0$ & $10.0 \pm 0.0$ \\
\hline $\mathrm{NH}_{4}{ }^{+}-\mathrm{N}$ & n.d. & $0.2 \pm 0.0$ & n.d. & n.d. & n.d. & $0.04 \pm 0.0$ \\
\hline $\mathrm{PO}_{4}{ }^{3-}-\mathrm{P}$ & n.d. & n.d. & n.d. & n.d. & n.d. & n.d. \\
\hline Coliforms & $1900 \pm 346$ & $2400 \pm 0$ & $2200 \pm 173$ & $4300 \pm 0$ & $2300 \pm 173$ & $2300 \pm 0$ \\
\hline Parameter & S7 & 58 & S9 & S10 & \multicolumn{2}{|c|}{ S11 } \\
\hline Temp & $29.4 \pm 0.3$ & $30.3 \pm 1.4$ & $29.6 \pm 0.3$ & $29.3 \pm 0.1$ & \multicolumn{2}{|c|}{$28.1 \pm 0.1$} \\
\hline $\mathrm{pH}$ & $7.71 \pm 0.03$ & $7.74 \pm 0.01$ & $7.56 \pm 0.01$ & $7.7 \pm 0.01$ & \multicolumn{2}{|c|}{$7.75 \pm 0.03$} \\
\hline Turbidity & $5.33 \pm 0.05$ & $6 \pm 0.05$ & $4.9 \pm 0.06$ & $11.43 \pm 0.06$ & \multicolumn{2}{|c|}{$9.03 \pm 0.09$} \\
\hline TSS & $47.0 \pm 0.0$ & $48.3 \pm 0.6$ & $49.7 \pm 0.6$ & $53.0 \pm 1.0$ & \multicolumn{2}{|c|}{$53.3 \pm 0.6$} \\
\hline DO & $8.0 \pm 0.1$ & $7.6 \pm 0.1$ & $8.0 \pm 0.1$ & $6.1 \pm 0.1$ & \multicolumn{2}{|c|}{$5.3 \pm 0.1$} \\
\hline COD & $16.0 \pm 0.0$ & $14.3 \pm 0.6$ & $15.3 \pm 0.6$ & $17.3 \pm 0.6$ & \multicolumn{2}{|c|}{$15.3 \pm 0.6$} \\
\hline $\mathrm{BOD}_{5}$ & $10.0 \pm 0.0$ & $9.3 \pm 0.6$ & $10.0 \pm 0.0$ & $11.3 \pm 0.6$ & \multicolumn{2}{|c|}{$10.0 \pm 0.0$} \\
\hline $\mathrm{NH}_{4}{ }^{+}-\mathrm{N}$ & n.d. & n.d. & n.d. & $0.1 \pm 0.0$ & \multicolumn{2}{|c|}{$0.22 \pm 0.0$} \\
\hline $\mathrm{PO}_{4}{ }^{3-}-\mathrm{P}$ & n.d. & n.d. & n.d. & n.d. & \multicolumn{2}{|c|}{$0.05 \pm 0.0$} \\
\hline Coliforms & $2200 \pm 173$ & $4600 \pm 0$ & $2300 \pm 0$ & $9300 \pm 0$ & \multicolumn{2}{|c|}{$9300 \pm 0$} \\
\hline
\end{tabular}

Note: $n$.d. = not detected (under detection limit)

\subsection{Water quality assessment using water quality index}

The water quality index (WQI) for sampling sites at Bung Binh Thien was presented in Figure 2. The WQI values classified water quality into two types, one was in good (S1-S9) and one is medium (S10-S11). According to National Environmental Protection Agency (2011) good water quality means WQI (90>WQ1>76) that the water could be used for domestic supply but proper treatment is required whereas medium water quality (75>WQ1>51) could be only used for agriculture and other equivalent uses. As previously discussed, water quality at the studied area ranged from medium to good due to the presence of relatively high concentrations of total suspended solids, organic matters, and coliforms. The bad water quality fell into one site in the river (S11) and one site receiving water from that river (S10) since the water flowed from S11 to S10 at the sampling time. This result was in accordance with the previous study revealing that water quality in rivers in the Mekong delta has been polluted for long period of time (Ministry of Natural Resources and Environment, 2012; People's Committee of An Giang Province, 2015).

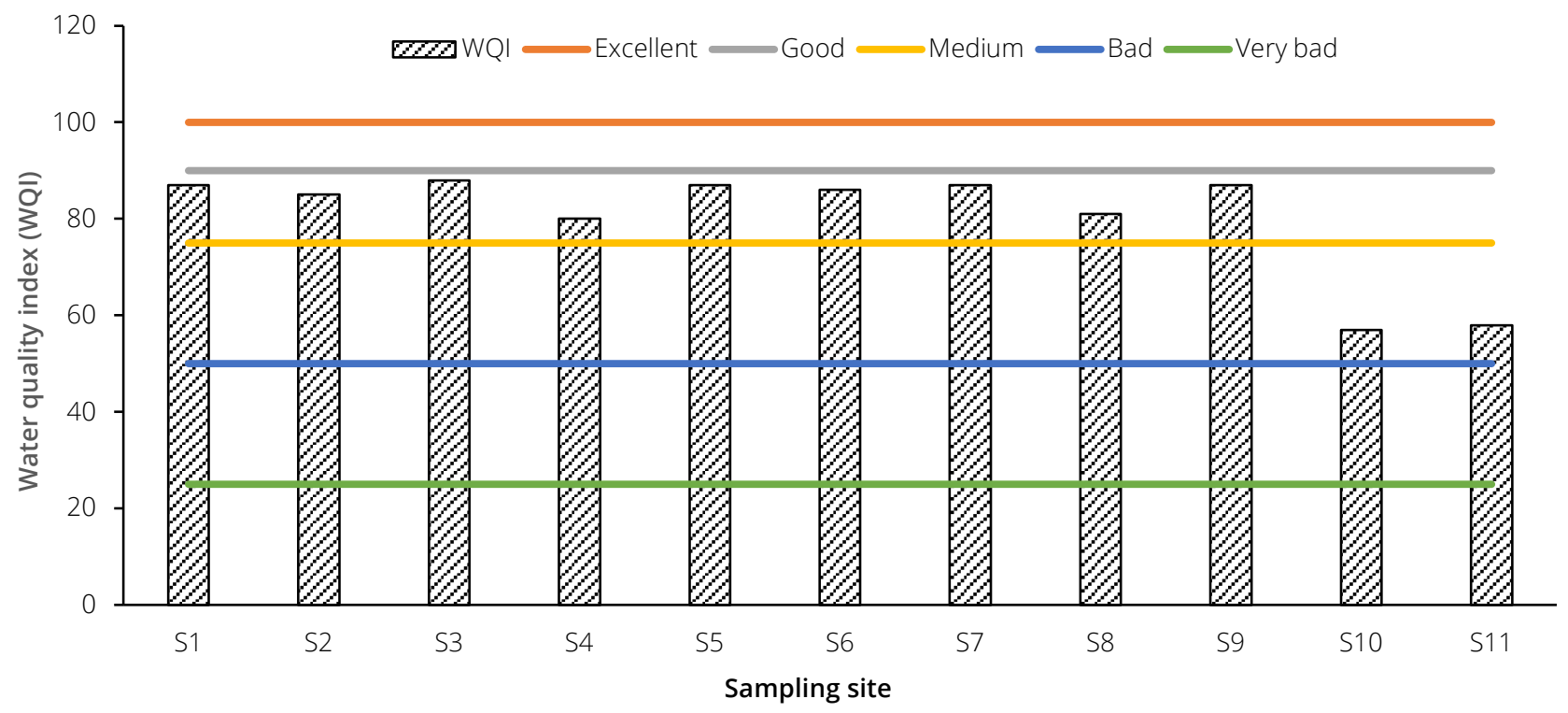

Figure 2. Water quality indexes at different sampling sites 


\subsection{Water quality assessment using phytoplankton}

Total 912 species of phytoplankton belonging to five phyla including Euglenophyta, Cyanophyta, Bacillariophyta, Chlorophyta and Dinophyta were found at the study sites. The numbers of species at the sampling locations ranged from 36 to 114 in which the lowest species numbers was found at site 11. Total density of phytoplankton ranged from 13,082 to 121,452 individuals/L and the lowest density was found at the site 11 . Total density of each phyla was from 12,340 to 285,143 individuals/L (Figure 3a). The percentage of Cyanophyta, Baccillariophyta, Chlorophyta, Dinophyta, and Euglenophyta were 44.0\%, 34.1\%, 16.7\%, $3.6 \%$, and $1.6 \%$, respectively (Figure $3 \mathrm{~b}$ ). The phytoplankton of Cyanophyta, Baccillariophyta, and Chlorophyta were also found dominated in constructed wetland (Cao et al., 2007) and rivers (Hoang et al., 2018; Duong et al., 2019). The proportions of Chlorophyta, Dinophyta and Euglenophyta were relatively stable from site S1 to S9 whereas the proportions of Cyanophyta and Bacillariophyta were highly oscillated. This fluctuation was because the composition of the phytoplankton at each site has changed probably due to environmental effects (i.e. turbulence, depth, and nutrient). Phytoplankton at site 11 was less abundant than the other sites. Phytoplankton at the site 10 was also less abundant than that of S1-S9 since S10 was much influenced by river water at the sampling time. The data of phytoplankton diversity and abundance corresponded with high turbidity and dissolved oxygen in water discussed in the previous section.

The presence of Bacillariophyta in the study area indicated water environment was in nutrient-rich (Oanh et al., 2014) and these phyla of phytoplankton is also very important for aquaculture (Lan, 2000). Chlorophyta is favorite food for other aquatic organisms especially fish, shrimp (Bac, 1998). Cyanophyta is widely distributed in nutrient-rich water environment (Oanh et al., 2014). It can utilize nitrogen from the air since it has nitrogenase enzyme. The fast growth of Cyanophyta could lead to eutrophication and cause harm for aquatic species. Cyanophyta is not good for aquaculture (Tien and Hanh, 1997). Euglenophyta widely distributed in static, high organic matters and nutrient-rich water bodies, however, Euglenophyta is not suitable for using as food by other aquatic organisms since its cell walls were hard and contain much mucus substances (Bac, 1998). Dinophyta or Pyrrophyta often occur in brackish or saline water (Oanh et al., 2014). It could release toxin causing harm for aquatic species, however, Dinophyta and Bacillariophyta could be the main food for zooplankton and shrimp larvae. The occurrence of phytoplankton at the sampling sites indicates several matters relating to water bodies, for instances, indicating nutrient- organic-rich water environment and taking part in food chains and food webs as well as facilitating nutrient cycles in water bodies. The compositional data of phytoplankton was in accordance with turbidity, suspended solids, organic matters, and dissolved oxygen.
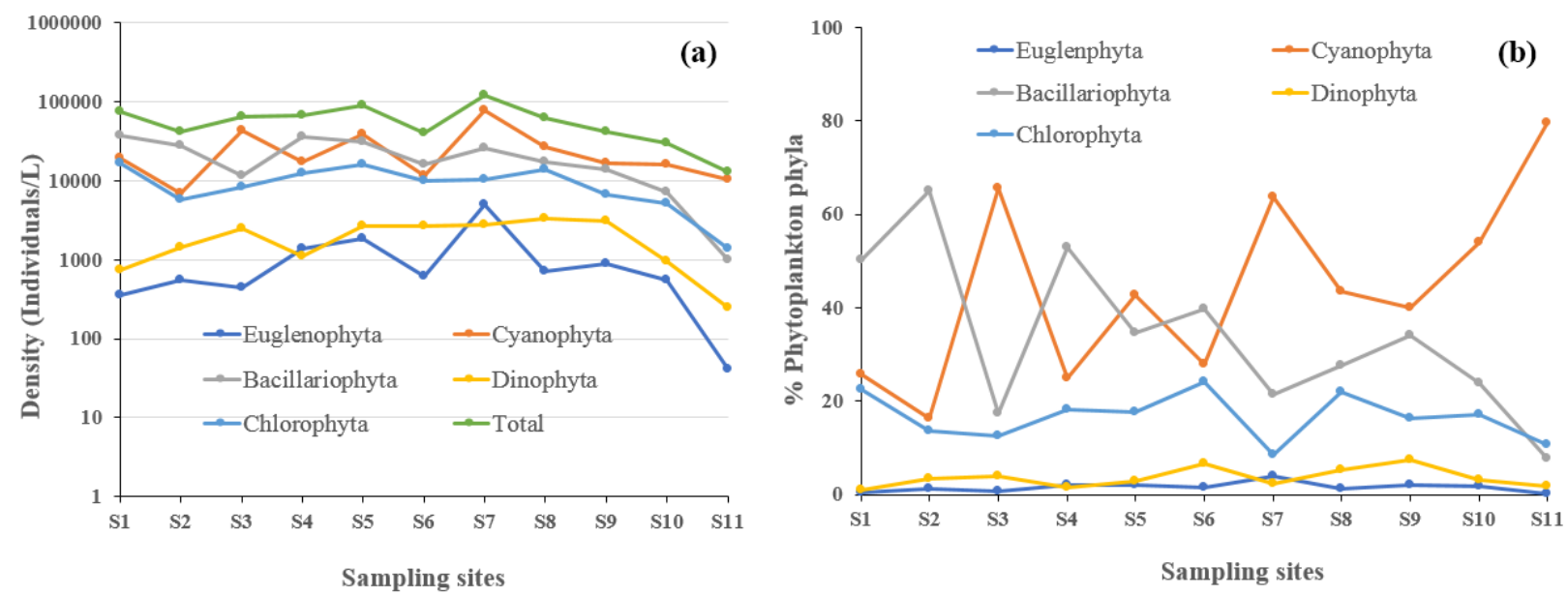

Figure 3. Density and composition of phytoplankton at Bung Binh Thien

The calculated Shannon-Wiener diversity index $\left(\mathrm{H}^{\prime}\right)$ was presented in Figure 4. The values of $\mathrm{H}^{\prime}$ ranged from 1.12 to 2.71 corresponding to the quality of the water from medium to bad. Water quality bad means the water could be used for water transportation and equivalent purposes. The medium water quality could be found at sites S1, S2,
S4, S5, S6, S8 and S9. The sites S3, S7, S10 and S11 were in bad water quality. The water quality at these sites closely related to the composition of phytoplankton that the occurrence of Bacillariophyta, Cyanophyta and Euglenophyta representing nutrient-and organic-rich environment. However, $\mathrm{H}^{\prime}$ showed worse water quality compared to WQI. 


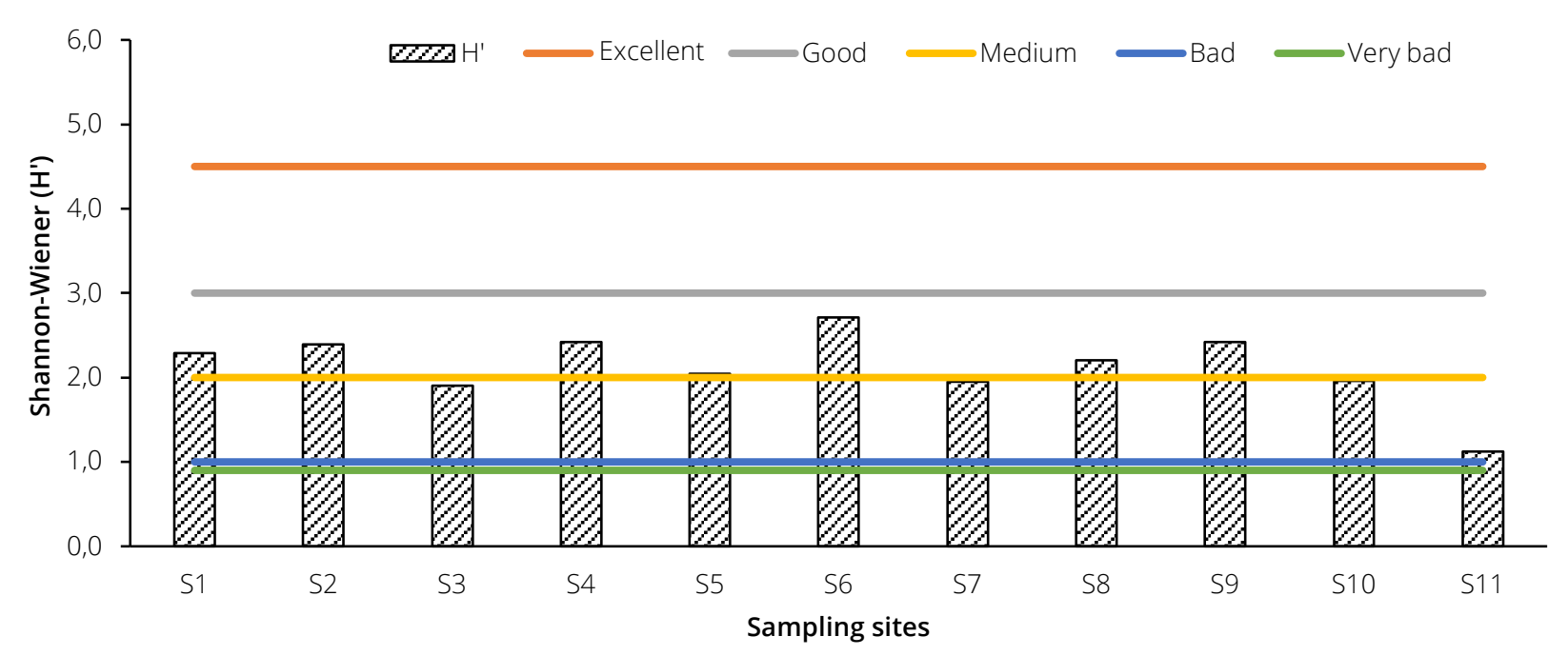

Figure 4. Water quality using Shannon-Weiner diversity index $\left(\mathrm{H}^{\prime}\right)$

\subsection{Water quality assessment using zoobenthos}

Total 6 classes and 17 families of zoobenthos were detected at the studied area. The six classes including Oligochaeta (1 family, 3 species), Polychaeta (1 family, 1 species), Insecta (5 families, 7 species), Gastropoda (2 family, 2 species), Bivalvia (4 families, 9 species), and Malacostraca (4 families, 4 species) were identified in which Polychaeta, Gastropoda, Bivalvia and Malacostraca were not or very rarely occurred at S1-S9, but appeared at S10-S11 (except Polychaeta). The Insecta and Oligochaeta were the frequent occurrence and dominant classes (Figure 5a). The species of Chaoborus astictopus, Metriocnemus Knabi coq belonging to families Culicidae, Chironomidae, respectively were the most frequent occurrence of the class of Insecta. The number of species at the study sites ranged from 1 to 19 species in which the lowest was at site 6 and the highest

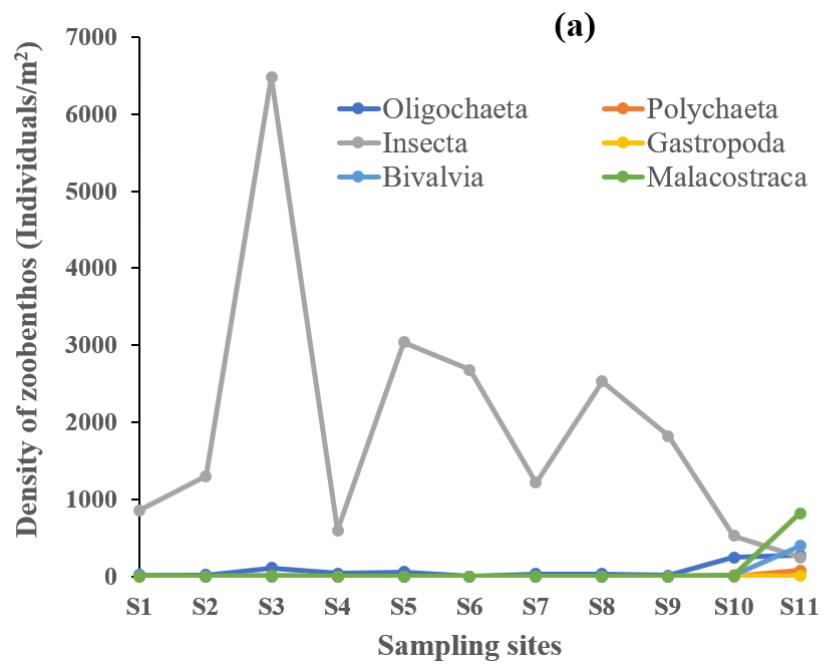

Figure 5. Density and composition of zoobenthos

The density of zoobenthos ranged from 640 to 6,600 individuals $/ \mathrm{m}^{2}$. The highest density was found at $\mathrm{S3}$. This could be due to the effect of waste discharging from the floating restaurant at the site. The density was mainly contributed by Oligochaeta and Polychaeta (Figure 5b). The densities of was at site 11. The less diversity of species of the zoobenthos in the site from S1 to S9 (1-5 species belonging to 1-2 classes) compared to S10-S11 (10-19 species belonging to 5-6 classes)) could indicate significant difference in the properties of the sediments. It was observed at the field that the sediment at site 10 and site 11 was hard, light color and contained sandy materials whereas sediment at site 1 to site 9 was soft and muddy, dark color, and contained organic matters. In the previous discussion, WQI indicated that water quality at S10 and S11 was much more polluted than that at S1-S9, however, the number of species of zoobenthos at S10 and S11 were significantly higher than those at S1-S9. This could be because zoobenthos indicate better for sediment environment as previously reported (Lien and Ut, 2016; Giao, 2019). Future research should also collect sediment sample for analysis of its properties to elaborate role of zoobenthos in indicating environment.

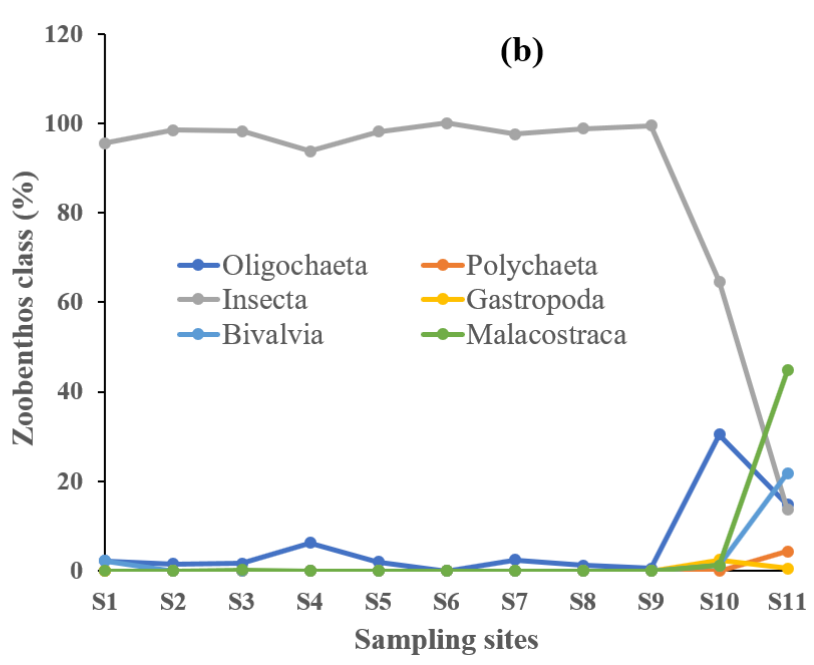

Oligochaeta and Polychaeta at the studied sites ranged from 10 to 270 and from 600 to 6,480 individuals $/ \mathrm{m}^{2}$, respectively (Figure 5a). Shannon-Weiner diversity index $\left(\mathrm{H}^{\prime}\right)$ calculated from zoobenthos diversity at the Bung Binh Thien fluctuated from 0 to 2.07 (Figure 6a). The values of $\mathrm{H}^{\prime}$ 
inside Bung Binh Thien (from S1 to S9) were lower than 1. This could mean that the water quality was very bad or heavily polluted (Bae and Lee, 2001). The water could only be used after appropriate treatment methods are applied. However, the values of $H^{\prime}$ at S10 (1.88) and S11 (2.07) revealed that water quality at those sites were better than S1-S9. It could also mean that the zoobenthos at site 10 and site 11 were more diverse than those at site S1-S9.

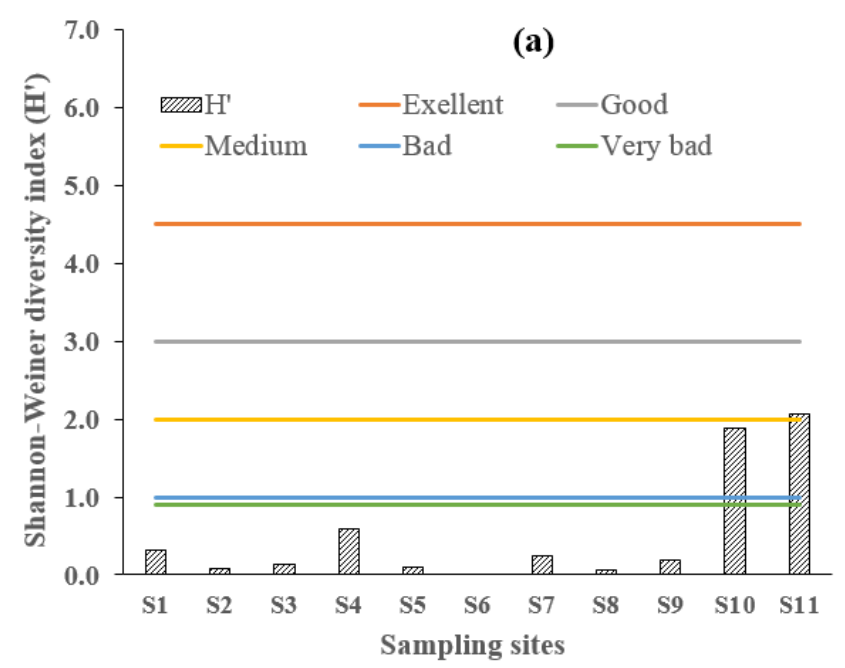

This was consistent with the data of composition of zoobenthos that five to six families of zoobenthos were discovered at S10 and S11 whereas only two or three families of zoobenthos were found at S1-S9. This could be due to the difference in the characteristics of the bottom sediments of the study sites. Further study should also collect the sediment samples at the same time with zoobenthos sampling for better data interpretation.

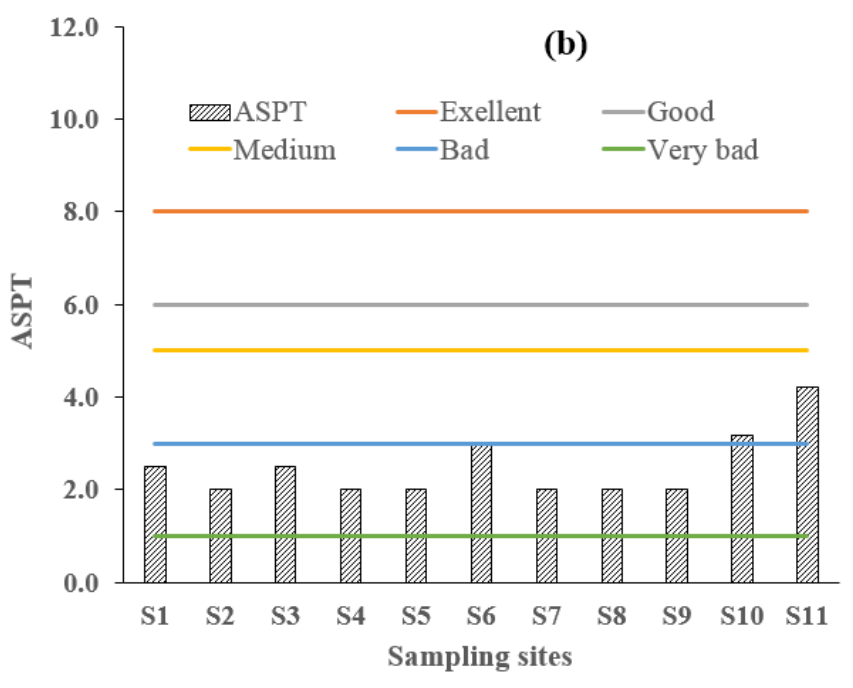

Figure 6. Water quality assessment using $\mathrm{H}^{\prime}$ and ASPT calculated from zoobenthos

The calculated values of ASPT based on the BMWPVIET for 11 sampling locations were illustrated in Figure 6b. The ASPT values divided water quality at two levels, one was bad quality or water quality for transportation (S10 and S11), one was very bad quality or heavily polluted (S1-S9). The use of biological indicators including using phytoplankton and zoobenthos for water quality assessment showed some inconsistency. In this study, the water quality index was used as standard quality for comparision with the water quality using $\mathrm{H}^{\prime}$ calculated from diversity of phytoplankton $\left(H^{\prime} p\right)$ and $H^{\prime}$ calculated from zoobenthos $\left(H^{\prime} z\right)$, ASPT calculated from zoobenthos. The comparing among WQI, H'p, H'z and ASPT was presented in Table 2.

Table 2. Comparing assessment of water quality using phytoplankton and zoobenthos

\begin{tabular}{|c|c|c|c|c|c|c|c|c|}
\hline Site & WQI & $\begin{array}{l}\text { Water } \\
\text { Quality }\end{array}$ & $\begin{array}{l}\mathrm{H}^{\prime} \\
\text { (Phytoplankton) }\end{array}$ & $\begin{array}{l}\text { Water } \\
\text { Quality }\end{array}$ & $\begin{array}{l}\mathrm{H}^{\prime} \\
\text { (Zoobenthos) }\end{array}$ & $\begin{array}{l}\text { Water } \\
\text { Quality }\end{array}$ & ASPT & $\begin{array}{l}\text { Water } \\
\text { Quality }\end{array}$ \\
\hline S1 & 87 & good & 2.29 & medium & 0.31 & very bad & 2.5 & very bad \\
\hline $\mathrm{S} 2$ & 85 & good & 2.39 & medium & 0.09 & very bad & 2.0 & very bad \\
\hline S3 & 88 & good & 1.91 & bad & 0.13 & very bad & 2.5 & very bad \\
\hline S4 & 80 & good & 2.42 & medium & 0.59 & very bad & 2.0 & very bad \\
\hline S5 & 87 & good & 2.04 & medium & 0.10 & very bad & 2.0 & very bad \\
\hline S6 & 86 & good & 2.71 & medium & 0.00 & very bad & 3.0 & very bad \\
\hline S7 & 87 & good & 1.95 & bad & 0.24 & very bad & 2.0 & very bad \\
\hline S8 & 81 & good & 2.20 & medium & 0.06 & very bad & 2.0 & very bad \\
\hline S9 & 87 & good & 2.42 & medium & 0.20 & very bad & 2.0 & very bad \\
\hline S10 & 57 & medium & 1.96 & bad & 1.88 & bad & 3.17 & bad \\
\hline S11 & 58 & medium & 1.12 & bad & 2.07 & medium & 4.21 & bad \\
\hline
\end{tabular}

The use of $\mathrm{H}^{\prime} \mathrm{p}$ for water quality prediction could lower water quality to one or two level, for example, from good water quality to medium or bad water quality. This could be the fact that phytoplankton diversity and composition depend on several factors such as nutrients, organic matter, light, bicarbonate and phytoplankton consumers (i.e, fish, zooplankton). Using H'z and ASPT values indicated very bad to bad water quality whereas WQI showed water quality from good to medium. Previous also indicated that the use
WQI for the assessment of the water quality could result in lesser pollution level than the use of H', ASPT calculated from zoobenthos (Giao, 2019) since zoobenthos could be affected by both the properties of sediments and the water column (Dung et al., 2011; Lien and Ut, 2016). However, using $\mathrm{H}^{\prime}$ and ASPT calculated from zoobenthos leading to the same water quality evaluation. This was also previously reported by Giao (2019). Therefore, the use of H' and ASPT should be carefully considered, for examples, the values of 
$\mathrm{H}^{\prime}$ of phytoplankton and zoobenthos were calculated mainly based on the diversity of species, but not species abundance; the obtained ASPT values mainly based on scoring the family of zoobenthos, and sometimes the utilization of zoobenthos for predicting the water quality may not be accurate since various species in the same family may have different capability of pollution tolerance (Dung et al., 2007). The results of the present study recommend that the Shannon-Wiener diversity index $\left(\mathrm{H}^{\prime}\right)$ and ASPT should not be solely used to evaluate water quality. Instead, it should be used in combination with physicochemical water parameters. H'z and ASPT should be used for bottom sediment quality assessment not for water quality assessment.

\section{Conclusions}

Water quality at Bung Binh Thien Lake in dry season was polluted by suspended solids, organic matters, and coliforms. The WQI values classified water quality from good to medium. There were found total 912 species belonged to five phyla of phytoplankton comprising Euglenophyta, Cyanophyta, Bacillariophyta, Chlorophyta and Dinophyta in which Bacillariophyta, Cyanophyta, and Chlorophyta were dominant. The numbers of species at the sampling locations ranged from 36 to 114 species and total density of phytoplankton were from 13,082 to 121,452 individuals/L. The values of H'of phytoplankton (1.12 to 2.71) indicated the quality of water from medium to bad. For zoobenthos, six classes including Oligochaeta, Polychaeta, Insecta, Gastropoda, Bivalvia, and Malacostraca were identified in which the Insecta and Oligochaeta were the most frequently occurred. The total density of zoobenthos was in the range of 640-6,600 individuals $/ \mathrm{m}^{2}$. Shannon-Weiner diversity index $\left(H^{\prime}\right)$ calculated from zoobenthos diversity were of 0-2.07 while calculated ASPT values were from 2 to 4.21. both $\mathrm{H}^{\prime}$ and $A S P T$ values divided water quality from bad to very bad quality or heavily polluted. There was inconsistency among water quality indices. WQI indicated water quality from good to medium, $\mathrm{H}^{\prime}$ of phytoplankton showed medium to bad whereas $\mathrm{H}^{\prime}$ and ASPT of zoobenthos indicated very bad to bad water quality. The results of the present study recommend that assessment of water quality should not totally only relied on biodiversity indices ( $\mathrm{H}^{\prime}, \mathrm{ASPT}$ ) but also analyze the composition of phytoplankton and zooplankton with the participation of the experts in the relevant fields.

\section{References}

[1] American Public Health Association (1998). Standard methods for the examination of water and wastewater, 20th edition, Washington DC, USA.

[2] Bae, Y.J. and Lee, B.H (2001). Human impacts on stream ecosystems and freshwater arthropods in Korea. Korean Journal of Entomology, 31, 63-76.

[3] Bac, T.C. (1998). Fundamental Ecology. Can Tho University Publishing House. (In Vietnamese)
[4] Bolstad, P.V., Swank, W.T. (1997). Cumulative impacts of landuse on water quality in a southern Appalachian watershed. J. Am. Water Resour. Assoc. 33 (3), 519533.

[5] Carpenter, K.E. and Niem, V.H (1998). The living marine resources of the Western central Pacifi Volume 1. Seaweeds, corals, bivalves and gastropods, FAO, Rome.

[6] Cho, K. H., Park, Y., Kang, J-H, Ki, S. J., Cha, S., Lee, S. W., and Kim, J. H. (2009). Interpretation of seasonal water quality variation in the Yeongsan Reservoir, Korea using multivariate statistical analyses. Water Science and Technology 59(11), 2219-2226.

[7] Chounlamany, V., Tanchuling, M.A., and Inoue, T. (2017). Spatial and temporal variation of water quality of a segment of Marikina river using multivariate statistical methods. Water Science and Technology 66(6), 1510-1522.

[8] Cao, L., Guisen, D., Bingbin, H., Qingyi, M., Huimin, L., Zijian, W. and Fu, S. (2007). Biodiversity and water quality variations in constructed wetland of Yongding River system. Acta Ecologica Sinica, 27(9), 3670-3677.

[9] Department of Natural Resources and Environment (2014). Statistics, inventory of land use and land use mapping.

[10] Duong, T.T., Hoang, H.T.T., Nguyen, K.T., Le, Q.T.P., Le, N.D., Dang, D.K., Lu, X., Bui, M.H., Trinh, Q.H., Dinh, T.H.V., Pham, T.D., Rochelle-newallj, E. (2019). Factors structuring phytoplankton community in a large tropical river: Case study in the Red River (Vietnam). Limnologica, 76, 82-93.

[11] Dung, D.T., Tam, D.T., and Be, N.V. (2007). Aquatic characteristics in the biodiversity area in the Agro-forestry Area 184, Ca Mau. Can Tho University Journal of Science, 7, 85-94 (in Vietnamese).

[12] Dung, D.T., Cong, N.V., and Quyen, L.C. (2011). Using zoobenthos indices for assessment of the polluted water in Tam Bot canal, Long Xuyen, An Giang province. Can Tho University Journal of Science, 20, 18-27.

[13] Fernando, C.H (2002). A guide to tropical freshwater zooplankton: identification, ecology and impact on fisheries. Backhuys Publishers, Leiden, The Netherlands.

[14] Galal-Gorchev, H., Ozolins, G., \& Bonnefoy, X. (1993). Revision of the $\mathrm{WHO}$ guidelines for drinking water quality. Annali dell' Istituto Superiore di Sanità, 29, 335-345.

[15] Giao, N.T. (2019). The use of zoobenthos for the assessment of water quality in canals influenced by landfilling and agricultural activity. Journal of Vietnamese Environment, 11(2), 33-42.

[16] Hung, N.Q (2010). Atlas of photos: The list of economic aquatic species is mainly in the mangrove ecosystem. Institute of Seafood Research. 
[17] Hayward, P.J. and Ryland, J.S (1990). The marine fauna of the British Isles and north-west Europe Vol 2. Molluscs to chordates, Oxford Clarendon Press.

[18] Ho, P. H (1972). Algae. Sai Gon Publishing House. (In Vietnamese).

[19] Hoang, H.T.T., Duong, T.T., Nguyen, K.T., Le, Q.T.P., Luu, M.T.N., Trinh, D. A, Le, H.A., Ho, C.T., Dang, K.D., Némery, J., Orange, D., and Klein, J. (2018). Impact of anthropogenic activities on water quality and plankton communities in the Day River (Red River Delta, Vietnam). Environmental Monitoring and Assessment, $190,67$.

[20] Kazi, T. G., Arain, M. B., Jamali, M. K., Jalbani, N., Afridi, H. I., Sarfraz, R. A. Shah, A. Q. (2009). Assessment of water quality of polluted lake using multivariate statistical techniques: A case study. Ecotoxicology and Environmental Safety, 72(20), 301-309.

[21] Ly, N.H.T., \& Giao, N.T. (2018). Surface water quality in canals in An Giang province, Viet Nam, from 2009 to 2016. Journal of Vietnamese Environment, 10(2), 113-119.

[22] Lan, L. M. (2000). Aquatic plants. Can Tho University Publishing House. (In Vietnamese)

[23] Lien, N.T.K and Ut, V.N (2016). Comparing development of zoobenthos at upper, middle and lower parts of Hau River. Journal of Science and Technology, 18, 94-102.

[24] Ministry of Natural Resources and Environment (2012). National State of Environment-Surface Water Quality, 2012, 112.

[25] Ministry of Natural Resources and Environment (2015). QCVN 08-MT: 2015/BTNMT National technical regulation on surface water quality.

[26] National Environmental Protection Agency (2011). Decision No. 879 /QĐ-TCMT-Guideline for calculating water quality index.

[27] Oanh, D.T.H., Giang, H.T., and Lien, N.T.K. (2014). Fluctuation of phytoplankton community in intensive white leg shrimp (Litopenaeus vannamei) ponds referring to shrimp health status. Can Tho University Journal of Science, 2014, 159-168.

[28] Oanh, D.T.H. and Lien, N.T.K. (2015). Zooplankton, natural food in the rotational rice-tiger shrimp (Penaeus monodon) system. Feed and Feeding Management for healthier Aquaculture and profits - The 7th Regional Aquafeed Forum hold at Can Tho University, 20-23 October 2015.

[29] Plafkin, J.L., M.T. Barbour., K.D. Porter., S. K. Gross and R.M. Hughes (1989), Rapid Bioassessment Protocols for Use in Streams and Rivers: Benthic Macroinvertebrates and Fish. EPA/444/4-89-001. U.S. Environ. Prot. Agency, Washington, D.C.
[30] People's Committee of An Giang province (2015). Report on the state of environment in five years (2011 2015) of An Giang province, 2015, 181.

[31] People's Committee of An Giang province (2010). Report on the state of environment in five years (2005 2009) of An Giang province, 2010, 178.

[32] Quynh, N.X., Pinder, C., Tilling, S (2001). Identification of Vietnam freshwater invertebrates, Scientific and Technical Publisher, Hanoi, Vietnam.

[33] Quynh, N. X., M. D. Yen., C. Pinder and S. Tilling (2000). Biological surveillance of freshwaters, using macroinvertebrates, A Practical Manual and Identification Key for Use in Vietnam Field Studies Council. UK.

[34] Richard, S.T., Thorne J. and Williams W.P (1997). The response of benthic macroinvertebrates to pollution in developing countries: a multimetric system of bioassessment. Freshwater Biology, 37, 671- 686.

[35] Singh, K. P., Malik, A. \& Sinha, S. (2005). Water quality assessment and apportionment of pollution sources of Gomti river (India) using multivariate statistical techniques - a case study. Analytica Chimica Acta 538, 355-374.

[36] Tien, D. D., and Hanh, V (1997). Freshwater algae in Vietnam - Classification of green algae. NXB Agricultural Publishing House. (In Vietnamese).

[37] Thanh, D.N., Bai, T.T., Mien, P.V (1980). Identification of North Vietnam freshwater invertebrates. Scientific and Technical Publisher, Hanoi, Vietnam.

[38] Tuyen, N.V (2003). Biodiversity in algae in Vietnam's inland waters. Prospects and challenges. Agriculture Publishing House. (In Vietnamese).

[39] UNICEF Handbook on Water Quality (2008). United Nations Children's Fund (UNICEF), New York.

[40] Wilhm, J. \& Dorris, T (1968). Biological parameters for water quality criteria. Biological Science, 18(6), 477 481.

[41] Wijeyaratne, W.M.D.N and Kalaotuwave, K.M.B.P.P. (2017). Evaluation of the water and sediment quality of a lotic water-body in the western coastal region of Sri Lanka using Rapid Bioassessment Protocol II (RBP II) of benthic macroinverterbrates. Sri Lanka Journal of Aquatic Science, 22(2), 85-97.

[42] Zamora, P.M. and Co, L (1986). Guide to Philippine Flora and Fauna, Natural Resources Management Center. Ministry of Natural Resources.

[43] Zeinalzadeh, K and Rezaei, E. (2017). Determining spatial and temporal changes of surface water quality using principal component analysis. Journal of Hydrology: Regional Studies 13, 1-10. 